\title{
Effect of macronutrients and gibberellic acid on photosynthetic machinery, nitrogen-fixation, cell metabolites and seed yield of chickpea (Cicer arietinum L.)
}

\begin{abstract}
An experiment was carried out with an aim to enhance the performance of chickpea by the spray of a small quantity of phosphorus $(\mathrm{P})$ and/or sulphur (S) with or without the soaking of GA treatment $\left(10^{-6} \mathrm{M} \mathrm{GA}\right.$ for $\left.8 \mathrm{~h}\right)$ and/ or the GA spray treatment $\left(10^{-6} \mathrm{M} \mathrm{GA}\right.$ at 60-70 DAS). P and $\mathrm{S}$ each at $2 \mathrm{~kg} / \mathrm{ha}$ were sprayed in two equal splits i.e. half at 60 and the remaining half at the 70 DAS alone or in combination with the GA treatment. Prior to sowing, total seeds of chickpea were grouped into two; one group of seeds was soaked in $0 \mathrm{M} \mathrm{GA}$ (control) and the other group were soaked in $10^{-6} \mathrm{M}$ GA aqueous solution, each for 8 hours. There were total sixteen treatments with ten combinations of $\mathrm{P}$ and/or $\mathrm{S}$ with GA are possible viz., $\mathrm{F}_{\mathrm{PS}}, \mathrm{S}_{\mathrm{GA}}+\mathrm{F}_{\mathrm{p}}, \mathrm{S}_{\mathrm{GA}}+\mathrm{F}_{\mathrm{S}}, \mathrm{S}_{\mathrm{GA}}+\mathrm{F}_{\mathrm{PS}}, \mathrm{F}_{\mathrm{GAP}}, \mathrm{F}_{\mathrm{GAS}}, \mathrm{F}_{\mathrm{GAPS}}, \mathrm{S}_{\mathrm{GA}}+\mathrm{F}_{\mathrm{GAP}}, \mathrm{S}_{\mathrm{GA}}+\mathrm{F}_{\mathrm{GAS}}$ and $\mathrm{S}_{\mathrm{GA}}+\mathrm{F}_{\mathrm{GAPS}}$. The combined application of $\mathrm{P}$ and $\mathrm{S}$ with $\mathrm{GA}$ showed better responses and further improvement in carbonic anhydrase (CA) activity, stomatal conductance $(g s)$, net photosynthetic rate $\left(P_{N}\right)$, nitrate reductase activity (NR), and leghemoglobin content (Lb) at two sampling stages (90 and $100 \mathrm{DAS}$ ). This treatment also increased pod number per plant, seed yield per plant and harvest index (HI), seed protein and carbohydrate content at harvest. This combination augmented the protein content $(21 \%)$, carbohydrate content $(11 \%)$, seed yield $(86 \%)$ and $\mathrm{HI}(91.78 \%)$.
\end{abstract}

Keywords: gibberellins, carbonic anhydrase, nitrate reductase, photosynthesis, chickpea, leghemoglobin, yield
Volume I Issue 4 - 2017

\author{
Mohammad Mazid,' Farha $\mathrm{Naz}^{2}$ \\ 'Faculty of applied sciences and Humanities, Invertis University, \\ India \\ ${ }^{2}$ Department of Plant Science, MJP Rohilkhand University, India
}

Correspondence: Mohammad Mazid, Faculty of Applied Sciences and Humanities, Invertis University, India, Email mazid@invertis.org

Received: October 31, 2017 | Published: November 29, 2017
Abbreviations: LB, leghemoglobin content; CA, carbonic anhydrase; PGRs, plant growth regulators

\section{Introduction}

Pulses are well known as good rotational crops and have achieved important place in the Indian cropping system to buildup sustainable agriculture. ${ }^{1}$ Among pulses, for production, chickpea (Cicer arietinum L.), occupies the first position in India and third position at global level after bean and soybean., ${ }^{2,3}$ Chickpea belongs to the family Leguminosae and one important grain legume cultivated in the world and principle component of Golden Revolution as well. It has multiple functions in the traditional farming systems. It is very nutritive and used as a protein adjunct to starchy diets. It is given as preventive diet to atherosclerosis and diabetes patients because of its rich source of $\mathrm{Ca}, \mathrm{P}, \mathrm{Mg}, \mathrm{Fe}$, and $\mathrm{K}$ content. $^{2}$ Its seeds contain about $20-29 \%$ protein, $59-61 \%$ carbohydrate, soluble sugars, ${ }^{3} 8 \% 3-4 \%$ fat, $3 \%$ fiber and 3\% ash. ${ }^{4,5}$ Moreover, its cultivation helps in sustaining soil fertility by fixing nitrogen $(\mathrm{N})$ and meets $80 \%$ of its $\mathrm{N}$ requirement from symbiotic $\mathrm{N}$ fixation and can fix up to 140 kilogram per hectare $(\mathrm{kg} / \mathrm{ha})$ per year from air, ${ }^{6}$ particularly in the dry and rain fed area. In addition, it is also widely used as green manure. India is the largest producer of chickpea followed by Australia, Pakistan and Turkey. ${ }^{3}$

This crop is grown on 8.21 million hectares of our country with the annual production of 7.48 million tonnes and average productivity of $911 \mathrm{~kg} / \mathrm{ha}$ (FAO 2012). Though chickpea is grown in our country in the largest area in comparison with the other countries of the world, but her productivity at $911 \mathrm{~kg} / \mathrm{ha}$ is much lower than those of the developed countries of world, such as $2833.3 \mathrm{~kg} / \mathrm{ha}$ of China, $1668.4 \mathrm{~kg} / \mathrm{ha}$ of Canada and $1488.6 \mathrm{~kg} / \mathrm{ha}$ of USA (FAO 2012). The productivity of chickpea is often low due to heavy flower drop and pod shedding leading to poor seed setting which have been shown not as a result of insect damage, but due to physiological mechanism. ${ }^{7}$ Farmers have a wrong notion that chickpea being a legume crop, does not need any nutrition and usually grow it on the marginal lands, without applying any fertilizer. The yield gap of chickpea may be attributed to improper agro-technology used by the farmers. Yield gap can be abridged, by adopting the advanced production technology accompanying with the use of PGRs, balanced nutrition, weed management and selection of high yielding varieties. ${ }^{8}$ Low inorganic matter content in the soil is one of the major causes of the deficiency of nutrients. ${ }^{9}$ Due attention towards nutrient management is not paid in case of low input high risk rain fed legume crops, frequently grown in low fertility soils. ${ }^{10}$ To maintain the fertility of soils, the supplies must compensate what was exported at the harvest time. The reports are generally uniform and reliable simple to manage.

They are, drawn from non-renewable resources ${ }^{11}$ Plant growth regulators (PGRs) and macronutrients are known to play a positive role in regulating flower drop, premature pods development, and enhancing yield potential in plants. The rain fed crop records low biomass production due to inadequate soil moisture and nutrient availability ultimately resulting in less yields. Among the multinutrient deficiencies, $\mathrm{P}$ and $\mathrm{S}$ deficiency is posing a serious problem particularly in pulse crops owing to their higher requirement of these nutrients. Diammonium phosphate is most commonly used in pulse crops which supplies N and P but not S. Moreover, limited use of single 
superphosphate aggravated S efficiency in soil. Thus, the decline in yield of chickpea has been mainly attributed to the deficiencies of $\mathrm{P}$ and $\mathrm{S}$ which are common in most of the soil. ${ }^{12}$ The production of chickpea has not keeping pace with the increasing domestic demands. PGRs help to increase the number of flowers, regulation of flowering and their retention, ${ }^{13}$ since the flowering is influenced by PGRs, the number of pods increases which results in an increase in yield..$^{14,15}$ The PGRs also influences various growth and biochemical parameters. Gibberellins are considered to be the most florigenic of known PGRs.

To meet the challenges of the low chickpea production and local requirements, there is need for multipronged strategy. In this context, efforts in the form of launching national programs and research projects have been made by governmental and nongovernmental organizations. However, it must be admitted that these efforts howsoever laudable have not yet succeeded in offsetting the undesired shortfall in the indigenous chickpea-market. Evolving as well as adopting the best strategy for triple-purpose crop that may be one of the endeavors to improve the situation of chickpea shortage. This would be possible through the increase the height of the plant and to improve seed yield. To attain such goal, the use of $\mathrm{GA}_{3}$ and $\mathrm{P}$ and $\mathrm{S}$ may play an important role as they are known to affect many facets of plant life including photosynthetic rate $\left(P_{\mathrm{N}}\right), \mathrm{N}$-fixation, water and mineral uptake, harvest index, in regulation of growth and development by enhancing cell elongation and cell differentiation thus augmenting plant height and seed yield. ${ }^{16}$

Moreover, $\mathrm{GA}_{3}$ inhibit the adventitious root formation but enhance a number of physiological processes including activity of ribulose-1,5bisphosphate carboxylase (RuBPcase), bunching of grapes, breaking of seed and bud dormancy, cell-wall plasticity, cell elongation, flowering, growth and yield of sugarcane, $P_{\mathrm{v}}$, parthenocarpy, protein-synthesis, phloem-loading, relative growth rate (RGR), stomatal aperture, senescence, stem-elongation, seed-germination, synthesis and secretion of hydrolyzing enzymes particularly $\alpha$-amylase for promoting hydrolysis of storage-reserves, transpiration rate, transcription of messenger (m)-RNA and vernalization and thus augmenting seed yield. ${ }^{17-20}$ However, plants cannot respond maximally to $\mathrm{GA}_{3}$ when the supply of nutrients is inadequate (Khan et al. 2002a). Moreover, the requirement of chickpea for nutrients is very high and further the intensive cropping systems may remove much of the applied nutrients under high productivity conditions. ${ }^{21}$

A considerable amount of fertilizers is rendered unavailable to the plant as it grows due to many factors, including leaching, fixation, decomposition and volatilization. For example, up to $50 \%$ of the soilapplied $\mathrm{N}, 22$ about $70 \%$ of the soil-applied $\mathrm{P}^{23}$ and as reported by, ${ }^{24}$ more or less $60 \%$ of the total applied S may be lost due to one or more of these reasons. Among mineral nutrients, $\mathrm{P}$ is an essential nutrient and an integral component of several important compounds, including adenosine triphosphate and other related high energy compounds, all sugar-phosphates in photosynthesis, co-enzymes, glycerol phosphatides, nucleic acids, nicotinamide adenine dinucleotide, nicotinamide adenine dinucleotide phosphate, phospholipids and phosphoglycerides. ${ }^{25} \mathrm{~S}$ is also represents the ninth and least abundant essential macro-elements in plants, proceeded by $\mathrm{C}, \mathrm{O}, \mathrm{H}, \mathrm{N}, \mathrm{K}, \mathrm{Ca}$, $\mathrm{Mg}$ and P. S plays critical roles in the catalytic and/or electro-chemical functions of the biomolecules in cells and also as signaling molecules for fundamental cellular functions. ${ }^{26} \mathrm{~S}$ is a constituent of many organic compounds, including alliins, biotin, co-enzyme-A, cysteine and methionine, ferredoxins, lipoic acid, glucosinolates, thiamine and thiamine-pyrophosphate. ${ }^{27}$
Ferredoxins are also important for nitrogen assimilation. Thus, $\mathrm{S}$ plays an important role in plant growth and in the regulation of plant development and required for protein, lipids, carbohydrates synthesis, NR and electron transport systems functionality. Considering the overwhelming importance of Cicer arietinum L. in soil fertility recovery as well as determination of the growth, development and yield responses of chickpea to $\mathrm{GA}_{3}, \mathrm{P}$ and $\mathrm{S}$ application singly or in combination, a experiment was laid out to test whether the spray of $\mathrm{P}$ and /or $\mathrm{S}$ in the presence or absence of $\mathrm{GA}_{3}$ will improve the performance of chickpea.

\section{Materials and methods}

\section{Experimental site}

Aligarh is one of the seventy five districts of Uttar Pradesh. ${ }^{28} \mathrm{It}$ is situated at $27.88^{\circ} \mathrm{N}$ latitude, $78.08^{\circ} \mathrm{E}$ longitude and $180 \mathrm{~m}$ average altitude with an area of $3700.4 \mathrm{sq} \mathrm{km}$. Its climate is sub-tropical, with severest hot dry summers and intense cold winters. The winter extends from the middle of October to the end of March. The average temperatures for December and January are about $15^{\circ} \mathrm{C}$ and $13^{\circ} \mathrm{C}$ respectively. The recorded extremely lower temperatures for any single day are $2^{\circ} \mathrm{C}$ and $0.5^{\circ} \mathrm{C}$ respectively. The summer extends from April to the end of June. The average temperatures are $34.5^{\circ} \mathrm{C}$ and $34^{\circ} \mathrm{C}$ while, the extreme maximum records of temperatures are $45^{\circ} \mathrm{C}$ and $45.5^{\circ} \mathrm{C}$ for May and June respectively. The monsoon extends from the end of June to the middle of October and the mean temperature ranges between $26^{\circ} \mathrm{C}$ to $30^{\circ} \mathrm{C}$. The average rainfall is $847.3 \mathrm{~mm}$. More than $85 \%$ of the total rainfall occurs during a short span of four months from June to September and the remaining showers are received during winter season, useful for Rabi crops. Some additional occasional rainfall during the summer is very rare, sporadic, and variable to a greater extent in amounts. $4 \%$ out of total rainfall occurs during this season on an average scale. The relative humidity of the winter season ranges between $56 \%$ to $77 \%$ with an average $66.5 \%$ that of the summer between $37 \%$ and $49 \%$ with an average of $43 \%$ and that of the monsoon seasons, between $63 \%$ and $73 \%$ with an average of $68 \%$. Aligarh district has the same soil composition and the appearances as those found generally in the plains of western Uttar Pradesh (Northern India). Different types of soil, such as sandy, loamy, sandy-loam and clayey loam are found in the district.

\section{Plant materials}

Authentic seeds of a newly released high yielding cultivar of chickpea, namely DCP 92-3 was obtained from the IIPR, Kanpur (Uttar Pradesh). After selecting seeds of uniform size, their viability was tested. The healthy seeds were soaked with double distilled water (DDW) for $2 \mathrm{~h}$ and then were surface sterilized with absolute ethyl alcohol followed by repeated washing with DDW. Subsequently, seeds were inoculated with the recommended strain of Rhizobium namely TAL 1148 and then were sown in earthen pots. The crop was shown on the $2^{\text {th }}$ October, 2012 and harvested on the $25^{\text {th }}$ March, 2013.

\section{Soil analysis and experimental design}

Just before sowing a composite soil sample, collecting randomly from each pot containing the homogenous mixture of soil and FYM (4:1) was analysed for the soil characteristics. The soil sample was analysed in the Soil Testing Laboratory, Government Agriculture Farm, Quarsi, and Aligarh for various physico-chemical properties. Texture, sandy loam; $\mathrm{pH}, 8.04$; E.C. $\left(\mathrm{dSm}^{-1}\right), 0.65$; N-P-K(Kg/ha), 210-34.32-209.20 respectively and calcium carbonate (\%),0.10. 
Before sowing, the earthen pots of equal size $(25 \mathrm{~cm}$ height $25 \mathrm{~cm}$ diameter) were filled with the homogenous mixture of soil and FYM in the ratio of $4: 1$ at the rate of $5 \mathrm{~kg} /$ pot. The required number of pots was arranged according to a simple randomized design in a net house of the Department of Botany. Just one day before the sowing, pots were irrigated lightly to provide necessary moisture for seed germination.

\section{Preparation of solutions of PGR and nutrients}

Prior to the foliar treatments, 100 milliliter $(\mathrm{ml})$ stock solution of GA at $10^{-3} \mathrm{M}$ was prepared. The amount of GA was dissolved in $10 \mathrm{ml}$ ethyl alcohol and the final volume was made $100 \mathrm{ml}$ using DDW. Further dilutions of the stock solutions were made with DDW as per requirement. $\mathrm{P}$ and $\mathrm{S}$ solution at $0.1 \%$ was used for foliar spray. For application of nutrients alone, DDW was used as solvent however, the hormone solution was treated as solvent when nutrients and hormone were applied together. The aim of this experiment was to maximize the performance of cultivar DCP 92-3 by the spray of a small quantity of $\mathrm{P}$ and/or $\mathrm{S}$ with or without the best soaking GA treatment $\left(10^{-6}\right.$ M GA for $8 \mathrm{~h}$ ), and/or the GA spray treatment (10-6 MGA at $60-70$ DAS) determined. $\mathrm{P}$ and $\mathrm{S}$ each at $2 \mathrm{~kg} / \mathrm{ha}$ were sprayed in two equal splits, i.e. half at 60 and the remaining half at the 70 DAS alone or in combination with the GA treatment. The sources of $\mathrm{P}$ and $\mathrm{S}$ were sodium dihydrogen-orthophosphate and sodium sulphate respectively. There were in all sixteen treatments with four replicates.

\section{Sampling and data collection}

One plant from each replicate was uprooted randomly at the various sampling stages to assess the performance of the crop on the basis of growth characters, physiological and biochemical characteristics, yield attributes and quality parameters. Physiological and biochemical characteristics were studied at 90 and 100 DAS while yield and quality parameters at harvest. The chlorophyll content was estimated in fresh leaves collected randomly from each replicate by the method of Arnon (1949). $P_{\mathrm{N}}$ is the total rate of photosynthetic $\mathrm{CO}_{2}$ fixation minus the rate of loss of $\mathrm{CO}_{2}$ during the respiration. The $P_{\mathrm{N}}$ was measured in fully expanded leaves of somewhat the same age in all replicates by using the Infra Red Gas Analizer (IRGA), LICOR-6400, Nebraska, and USA). Each observation was repeated thrice. All the measurements were made on cloudless clear days between $11.00 \mathrm{O}$ ' clock and 12.00 Noon. The $P_{\mathrm{N}}$ was expressed in terms of $\mu \mathrm{mol}\left(\mathrm{CO}_{2}\right)$ $\mathrm{m}^{-2}$ second $(\mathrm{s})^{-1} . g s$ is a numerical measure of the maximum rate of passage of either water vapour or $\mathrm{CO}_{2}$ through the stomata.

It was also measured by the IRGA simultaneously with $P_{\mathrm{N}}$ Gs were expressed in terms of mol m $\mathrm{m}^{-2} \mathrm{~s}^{-1}$. CA activity was determined in fresh leaves collected randomly from each replicate. The enzyme CA catalyzes the reversible hydration of $\mathrm{CO}_{2}$ to give the bicarbonate ion $\left(\mathrm{HCO}_{3}^{-}\right)$. The activity of the enzyme was estimated by adopting the method of. ${ }^{29}$ The NR activity in fresh leaves was estimated by the method of. ${ }^{30}$ The leghaemoglobin content in fresh nodules was estimated following the method described by Sadasivam and. ${ }^{31}$ To assess the yield performance of the crop, the remaining two plants from each pot were harvested at maturity. The harvested plants were sun-dried in a net-house to prevent losses. After drying the crop, each sample was threshed individually. Number of pods per plant was determined at physiological maturity from two remaining plants. The pods were manually removed from all the harvested plants and number of pods per plant determined. The seeds were utilized for assessing the other characteristics. The total seeds of two plants were threshed, cleaned and allowed to dry in the sun for some time and their weight was obtained with the help of an electronic balance, with expressing their weight on per plant basis. The proportions of the biological yield representing the economic yield are called HI. The HI was computed by dividing the seed yield (economic yield) of a plant by the biological yield of the plant and expressed on percent basis. HI was calculated by the following formula:

$$
H I=\frac{\text { Economic yield }}{\text { Biol og ical yield }} \times 100
$$

The total seed protein and carbohydrate content in the dry seeds was estimated by adopting the methodology of. ${ }^{32}$ All data were analyzed statistically adopting the analysis of variance technique, according to.$^{33} \mathrm{In}$ applying the $\mathrm{F}$ test, the error due to replicates was also determined. When ' $F$ ' value was found to be significant at $5 \%$ level of probability, critical difference (CD) was calculated.

\section{Results and discussion}

\section{Photosynthetic variables}

Treatment $\mathrm{S}_{\mathrm{GA}}+\mathrm{F}_{\mathrm{GAPS}}$ gave the maximum value of chlorophyll content at both sampling stages. Its effect was, however, equal to that of $\mathrm{S}_{\mathrm{GA}}+\mathrm{F}_{\mathrm{GAP}}, \mathrm{S}_{\mathrm{GA}}+\mathrm{F}_{\mathrm{GAS}}, \mathrm{S}_{\mathrm{GA}}+\mathrm{F}_{\mathrm{GA}}, \mathrm{F}_{\mathrm{GAS}}$ and $\mathrm{F}_{\mathrm{GAP}}$ at each stage of sampling and also to that of $\mathrm{F}_{\mathrm{GA}}$ at $90 \mathrm{DAS}$. Treatment $\mathrm{S}_{\mathrm{GA}}+\mathrm{F}_{\mathrm{GAPS}}$ gave 46.16 and $48.84 \%$ higher value at 90 and 100 DAS respectively than $\mathrm{F}_{\mathrm{W}}$ (Table 1). At $90 \mathrm{DAS}$, treatment $\mathrm{S}_{\mathrm{GA}}+\mathrm{F}_{\mathrm{GAPS}}$ gave the maximum value of $P_{N}$ and its effect was however, at par with that of $\mathrm{S}_{\mathrm{GA}}+\mathrm{F}_{\mathrm{GAS}}$ and $\mathrm{S}_{\mathrm{GA}}+\mathrm{F}_{\mathrm{GAP}}$. At $100 \mathrm{DAS}$, treatment $\mathrm{S}_{\mathrm{GA}}+\mathrm{F}_{\mathrm{GAS}}$ gave the highest value, with its effect being by that of $\mathrm{S}_{\mathrm{GA}}+\mathrm{F}_{\mathrm{GAP}}$ and $\mathrm{S}_{\mathrm{GA}}+\mathrm{F}_{\mathrm{GAPS}}$ (Table 2). Treatment $S_{G A}+F_{\text {GAPS }}$ gave 64.24 and $65.37 \%$ higher value at 90 and 100 DAS respectively than $\mathrm{F}_{\mathrm{w}}$. The effect of treatments on $g \mathrm{~s}$ was found non-significant at both stages of sampling. The effect of treatments on $g s$ was found non-significant at both stages of sampling (Table 3). Treatment $\mathrm{S}_{\mathrm{GA}}+\mathrm{F}_{\mathrm{GAPS}}$ gave the maximum value of $\mathrm{CA}$ at 90 DAS. Its effect was, however, equal to that of $\mathrm{S}_{\mathrm{GA}}+\mathrm{F}_{\mathrm{GAS}}, \mathrm{S}_{\mathrm{GAPS}}$, $\mathrm{F}_{\mathrm{GA}}+\mathrm{F}_{\mathrm{GAP}}$ and $\mathrm{F}_{\mathrm{GAPS}}$ at 90 DAS. Treatment $\mathrm{S}_{\mathrm{GA}}+\mathrm{F}_{\mathrm{GAPS}}$ gave $64.56 \%$ higher value than $\mathrm{F}_{\mathrm{W}}$ at 90 DAS. However, this parameter was not affected by treatments at 100 DAS (Table 4). Treatment $\mathrm{S}_{\mathrm{GA}}+\mathrm{F}_{\mathrm{GAPS}}$ gave the maximum value of $\mathrm{NR}$ at each sampling stage. Its effect was, however, equaled by that of $\mathrm{S}_{\mathrm{GA}}+\mathrm{F}_{\mathrm{PS}}, \mathrm{F}_{\mathrm{GAPS}}, \mathrm{S}_{\mathrm{GA}}+\mathrm{F}_{\mathrm{GAS}}$ at both stages and was also by that of $\mathrm{S}_{\mathrm{GA}}+\mathrm{F}_{\mathrm{S}}$ at 100 DAS. Treatment $\mathrm{S}_{\mathrm{GA}}+\mathrm{F}_{\mathrm{GAPS}}$ gave 22.37 and $22.46 \%$ higher value at 90 and 100 DAS respectively than $\mathrm{F}_{\mathrm{W}}$ (Table 5). Treatments $\mathrm{S}_{\mathrm{GA}}+\mathrm{F}_{\mathrm{GAPS}}$ and $\mathrm{S}_{\mathrm{GA}}+\mathrm{F}_{\mathrm{GAS}}$ were at par in their effect and gave maximum value of $\mathrm{Lb}$ at each stage of sampling. Treatments, $\mathrm{F}_{\mathrm{GAPS}}, \mathrm{S}_{\mathrm{GA}}+\mathrm{F}_{\mathrm{GAP}}$ and $\mathrm{F}_{\mathrm{GAS}}$ being at par occupied second position at each stage and treatments $\mathrm{F}_{\mathrm{GAP}}, \mathrm{S}_{\mathrm{GA}}+\mathrm{F}_{\mathrm{PS}}$ and $\mathrm{F}_{\mathrm{GAS}}$ also at 90 DAS. Treatment $\mathrm{S}_{\mathrm{GA}}+\mathrm{F}_{\mathrm{GAPS}}$ gave 206.13 and $215.38 \%$ higher value at 90 and 100 DAS respectively than $\mathrm{F}_{\mathrm{W}}$ (Table 6).

PGRs are important control agents for growth and development of plants. ${ }^{34-38}$ In view of their crucial roles in different facets of plant life and very small quantity involved (economic), it is reasonable to use of PGRs in innovative farm cultural practices. Among PGRs, GA occupies a prominent position in mediating a variety of plant physiological processes including seed germination, leaf expansion, flower and fruit set, dry matter production, photosynthesis, translocation of food material and synthesis of mRNA coding for hydrolytic enzymes. ${ }^{39-45}$ The superiority of GA to the above mentioned PGRs has also been substantiated in the author's preliminary experiment. ${ }^{46}$ Keeping its prominent role in various physiological processes of plants, it is logical to exploit its potential by way of establishing its (i) adequate level and soaking duration for pre-sowing seed treatment, appropriate concentration and operational growth stage/s for foliar application and, mode of application (through foliage and /or seeds). 
Table I Effect of spray of $\mathrm{P}$ and /or $\mathrm{S}$ in the presence or absence of soaking and /or spray treatment of GA on chlorophyll content of chickpea cultivar DCP 92-3 at two growth stages (mean of four replicates)

\begin{tabular}{|c|c|c|}
\hline \multicolumn{3}{|c|}{ Chlorophyll content $\left[\mathrm{Mg} \mathrm{G}^{-1}\right.$ (F.M.) ] } \\
\hline Treatments & 90 DAS & I00 DAS \\
\hline $\mathrm{F}_{\mathrm{w}}$ & 1.69 & 1.72 \\
\hline $\mathrm{F}_{\mathrm{P}}$ & 1.81 & 1.84 \\
\hline $\mathrm{F}_{\mathrm{s}}$ & 1.94 & 1.97 \\
\hline $\mathrm{F}_{\mathrm{PS}}$ & 1.97 & 2 \\
\hline $\mathrm{S}_{\mathrm{GA}}$ & 2.14 & 2.21 \\
\hline $\mathrm{S}_{\mathrm{GA}}+\mathrm{F}_{\mathrm{P}}$ & 2.17 & 2.2 \\
\hline $\mathrm{S}_{G A}+F_{S}$ & 2.19 & 2.2 \\
\hline $\mathrm{S}_{\mathrm{GA}}+\mathrm{F}_{\mathrm{PS}}$ & 2.24 & 2.29 \\
\hline $\mathrm{F}_{\mathrm{GA}}$ & 2.37 & 2.39 \\
\hline $\mathrm{F}_{\mathrm{GAP}}$ & 2.39 & 2.4 \\
\hline $\mathrm{F}_{\mathrm{GAS}}$ & 2.35 & 2.38 \\
\hline $\mathrm{F}_{\mathrm{GAPS}}$ & 2.4 & 2.41 \\
\hline $\mathrm{S}_{\mathrm{GA}}+\mathrm{F}_{\mathrm{GA}}$ & 2.42 & 2.5 \\
\hline $\mathrm{S}_{\mathrm{GA}}+\mathrm{F}_{\mathrm{GAP}}$ & 2.44 & 2.53 \\
\hline $\mathrm{S}_{\mathrm{GA}}+\mathrm{F}_{\mathrm{GAS}}$ & 2.43 & 2.49 \\
\hline $\mathrm{S}_{\mathrm{GA}}+\mathrm{F}_{\mathrm{GAPS}}$ & 2.47 & 2.56 \\
\hline C.D. at $5 \%$ & 0.156 & 0.56 \\
\hline
\end{tabular}

N.B, A uniform basal dose of $40 \mathrm{kgN}+30 \mathrm{~kg} \mathrm{P}_{2} \mathrm{O}_{5} /$ ha was given to all pots.

Table 2 Effect of spray of $\mathrm{P}$ and /or $\mathrm{S}$ in the presence or absence of soaking and /or spray treatment of GA on net photosynthetic rate of chickpea cultivar DCP 92-3 at two growth stages (mean of four replicates)

\begin{tabular}{|c|c|c|}
\hline \multicolumn{3}{|c|}{ Net photosynthetic rate $\left(\mathrm{M} \mathrm{M} \mathrm{CO}_{2} \mathrm{M}^{-2} \mathrm{~S}^{-1}\right)$} \\
\hline Treatments & 90 DAS & IOO DAS \\
\hline $\mathrm{F}_{\mathrm{w}}$ & 7.16 & 6.64 \\
\hline $\mathrm{F}_{\mathrm{p}}$ & 8.1 & 7.54 \\
\hline $\mathrm{F}_{\mathrm{s}}$ & 8.27 & 7.84 \\
\hline $\mathrm{F}_{\mathrm{PS}}$ & 9.11 & 8.84 \\
\hline $\mathrm{S}_{\mathrm{GA}}$ & 7.61 & 8.2 \\
\hline $\mathrm{S}_{G A}+F_{P}$ & 8.64 & 8.29 \\
\hline $\mathrm{S}_{\mathrm{GA}}+\mathrm{F}_{\mathrm{S}}$ & 8.94 & 8.4 \\
\hline $\mathrm{S}_{\mathrm{GA}}+\mathrm{F}_{\mathrm{PS}}$ & 9.27 & 8.24 \\
\hline $\mathrm{F}_{\mathrm{GA}}$ & 9 & 8.97 \\
\hline $\mathrm{F}_{\mathrm{GAP}}$ & 10.44 & 9.92 \\
\hline $\mathrm{F}_{\mathrm{GAS}}$ & 10.45 & 9.97 \\
\hline $\mathrm{F}_{\text {GAPS }}$ & 10.4 & 10.13 \\
\hline$S_{G A}+F_{G A}$ & 10.4 & 10.1 \\
\hline $\mathrm{S}_{\mathrm{GA}}+\mathrm{F}_{\mathrm{GAP}}$ & 11.44 & 10.87 \\
\hline $\mathrm{S}_{\mathrm{GA}}+\mathrm{F}_{\mathrm{GAS}}$ & 11.54 & 10.98 \\
\hline $\mathrm{S}_{\mathrm{GA}}+\mathrm{F}_{\mathrm{GAPS}}$ & 11.76 & 10.7 \\
\hline C.D. at $5 \%$ & 0.68 & 0.64 \\
\hline
\end{tabular}

N.B,A uniform basal dose of $40 \mathrm{kgN}+30 \mathrm{~kg} \mathrm{P}_{2} \mathrm{O}_{5} / \mathrm{ha}$ was given to all pots.
Table 3 Effect of spray of $\mathrm{P}$ and /or $\mathrm{S}$ in the presence or absence of soaking and /or spray treatment of GA on stomatal conductance of chickpea cultivar DCP 92-3 at two growth stages (mean of four replicates)

\begin{tabular}{|c|c|c|}
\hline \multicolumn{3}{|c|}{ Stomatal conductance ( $\mathbf{M} \mathrm{Mol}^{\left.\mathbf{M}^{-2} \mathrm{~S}^{-1}\right)}$} \\
\hline Treatments & 90 DAS & 100 DAS \\
\hline $\mathrm{F}_{\mathrm{w}}$ & 0.19 & 0.17 \\
\hline $\mathrm{F}_{\mathrm{P}}$ & 0.192 & 0.17 \\
\hline $\mathrm{F}_{\mathrm{s}}$ & 0.197 & 0.172 \\
\hline $\mathrm{F}_{\mathrm{PS}}$ & 0.197 & 0.177 \\
\hline $\mathrm{S}_{\mathrm{GA}}$ & 0.2 & 0.192 \\
\hline $\mathrm{S}_{\mathrm{GA}}+\mathrm{F}_{\mathrm{P}}$ & 0.211 & 0.193 \\
\hline $\mathrm{S}_{\mathrm{GA}}+\mathrm{F}_{\mathrm{S}}$ & 0.213 & 0.19 \\
\hline $\mathrm{S}_{\mathrm{GA}}+\mathrm{F}_{\mathrm{PS}}$ & 0.213 & 0.2 \\
\hline $\mathrm{F}_{\mathrm{GA}}$ & 0.218 & 0.201 \\
\hline $\mathrm{F}_{\mathrm{GAP}}$ & 0.223 & 0.207 \\
\hline $\mathrm{F}_{\mathrm{GAS}}$ & 0.224 & 0.21 \\
\hline $\mathrm{F}_{\text {GAPS }}$ & 0.218 & 0.21 \\
\hline $\mathrm{S}_{\mathrm{GA}}+\mathrm{F}_{\mathrm{GA}}$ & 0.211 & 0.211 \\
\hline $\mathrm{S}_{\mathrm{GA}}+\mathrm{F}_{\mathrm{GAP}}$ & 0.226 & 0.211 \\
\hline $\mathrm{S}_{\mathrm{GA}}+\mathrm{F}_{\mathrm{GAS}}$ & 0.217 & 0.209 \\
\hline $\mathrm{S}_{\mathrm{GA}}+\mathrm{F}_{\mathrm{GAPS}}$ & 0.227 & 0.225 \\
\hline C.D. at $5 \%$ & NS & NS \\
\hline
\end{tabular}

N.B,A uniform basal dose of $40 \mathrm{kgN}+30 \mathrm{~kg} \mathrm{P}_{2} \mathrm{O}_{5} /$ ha was given to all pots.

Table 4 Effect of spray of $P$ and /or $S$ in the presence or absence of soaking and /or spray treatment of GA on carbonic anhydrase activity [mol $\mathrm{CO}_{2} \mathrm{~kg}$ '(F.M.) $\mathrm{s}^{-1}$ ] of chickpea cultivar DCP 92-3 at two growth stages (mean of four replicates)

\begin{tabular}{lll}
\hline Carbonic anhydrase activity $\left[\mathrm{Mol} \mathrm{CO}_{\mathbf{2}} \mathbf{K g}^{-1}\right.$ & (F.M.) $\left.\mathbf{S}^{-1}\right]$ \\
\hline Treatments & $\mathbf{9 0}$ DAS & $\mathbf{l}$ O0 DAS \\
\hline $\mathrm{F}_{\mathrm{W}}$ & 2.37 & 2.49 \\
$\mathrm{~F}_{\mathrm{P}}$ & 2.39 & $2.8 \mathrm{I}$ \\
$\mathrm{F}_{\mathrm{S}}$ & 2.46 & 2.74 \\
$\mathrm{~F}_{\mathrm{PS}}$ & 2.74 & 2.87 \\
$\mathrm{~S}_{\mathrm{GA}}$ & 3.41 & 3.42 \\
$\mathrm{~S}_{\mathrm{GA}}+\mathrm{F}_{\mathrm{P}}$ & 3.44 & 3.58 \\
$\mathrm{~S}_{\mathrm{GA}}+\mathrm{F}_{\mathrm{S}}$ & 3.5 & 3.63 \\
$\mathrm{~S}_{\mathrm{GA}}+\mathrm{F}_{\mathrm{PS}}$ & 3.78 & 3.92 \\
$\mathrm{~F}_{\mathrm{GA}}$ & 3.57 & 3.6 \\
$\mathrm{~F}_{\mathrm{GAP}}$ & 3.63 & 3.65 \\
$\mathrm{~F}_{\mathrm{GAS}}$ & 3.74 & 3.77 \\
$\mathrm{~F}_{\mathrm{GAPS}}$ & 3.84 & 3.9 \\
$\mathrm{~S}_{\mathrm{GA}}+\mathrm{F}_{\mathrm{GA}}$ & 3.71 & 3.76 \\
$\mathrm{~S}_{\mathrm{GA}}+\mathrm{F}_{\mathrm{GAP}}$ & 3.79 & 3.8 \\
$\mathrm{~S}_{\mathrm{GA}}+\mathrm{F}_{\mathrm{GAS}}$ & 3.85 & 3.86 \\
$\mathrm{~S}_{\mathrm{GA}}+\mathrm{F}_{\mathrm{GAPS}}$ & 3.9 & 3.94 \\
$\mathrm{C} . \mathrm{D}$. at $5 \%$ & 0.236 & $\mathrm{NS}$
\end{tabular}

$\mathrm{N} . \mathrm{B}, \mathrm{A}$ uniform basal dose of $40 \mathrm{kgN}+30 \mathrm{~kg} \mathrm{P}_{2} \mathrm{O}_{5} /$ ha was given to all pots. 
Table 5 Effect of spray of $\mathrm{P}$ and /or $\mathrm{S}$ in the presence or absence of soaking and /or spray treatment of GA on nitrate reductase activity of chickpea cultivar DCP 92-3 at two growth stages (mean of four replicates)

\begin{tabular}{|c|c|c|}
\hline \multicolumn{3}{|c|}{ Nitrate reductase activity $\mathrm{N}\left[\mathrm{Mol} \mathrm{NO}_{2^{-}} / \mathrm{G} /(\right.$ Leaf $\left.\mathrm{FW}) / \mathrm{H}\right]$} \\
\hline Treatments & 90 DAS & 100 DAS \\
\hline $\mathrm{F}_{\mathrm{w}}$ & 300 & 305.42 \\
\hline $\mathrm{F}_{\mathrm{p}}$ & 320.4 & 327.1 \\
\hline $\mathrm{F}_{\mathrm{s}}$ & 337.8 & 342.45 \\
\hline $\mathrm{F}_{\mathrm{PS}}$ & 340.1 & 347.1 \\
\hline $\mathrm{S}_{\mathrm{GA}}$ & 302.4 & 309.2 \\
\hline $\mathrm{S}_{\mathrm{GA}}+\mathrm{F}_{\mathrm{P}}$ & 309.4 & 313.4 \\
\hline $\mathrm{S}_{\mathrm{GA}}+\mathrm{F}_{\mathrm{S}}$ & 341.3 & 350.2 \\
\hline $\mathrm{S}_{\mathrm{GA}}+\mathrm{F}_{\mathrm{PS}}$ & 357.2 & 363.4 \\
\hline $\mathrm{F}_{\mathrm{GA}}$ & 304.1 & 307.2 \\
\hline $\mathrm{F}_{\mathrm{GAP}}$ & 307 & 319.4 \\
\hline $\mathrm{F}_{\mathrm{GAS}}$ & 317.3 & 330.2 \\
\hline $\mathrm{F}_{\mathrm{GAPS}}$ & 353.4 & 357.9 \\
\hline $\mathrm{S}_{\mathrm{GA}}+\mathrm{F}_{\mathrm{GA}}$ & 327.1 & 341.2 \\
\hline $\mathrm{S}_{\mathrm{GA}}+\mathrm{F}_{\mathrm{GAP}}$ & 340.2 & 347.4 \\
\hline $\mathrm{S}_{\mathrm{GA}}+\mathrm{F}_{\mathrm{GAS}}$ & 347.2 & 370.4 \\
\hline $\mathrm{S}_{\mathrm{GA}}+\mathrm{F}_{\mathrm{GAPS}}$ & 367.1 & 374 \\
\hline C.D. at $5 \%$ & 23.44 & 24.01 \\
\hline
\end{tabular}

N.B,A uniform basal dose of $40 \mathrm{kgN}+30 \mathrm{~kg} \mathrm{P}_{2} \mathrm{O}_{5} / \mathrm{ha}$ was given to all pots

Table 6 Effect of spray of $\mathrm{P}$ and /or $\mathrm{S}$ in the presence or absence of soaking and /or spray treatment of GA on Leghaemoglobin content of chickpea cultivar DCP 92-3 at two growth stages (mean of four replicates)

\begin{tabular}{|c|c|c|}
\hline \multicolumn{3}{|c|}{ Leghaemoglobin content Mg G-1 (F.M)) } \\
\hline Treatments & 90 DAS & 100 DAS \\
\hline $\mathrm{F}_{\mathrm{w}}$ & 0.147 & 0.13 \\
\hline $\mathrm{F}_{\mathrm{p}}$ & 0.157 & 0.15 \\
\hline $\mathrm{F}_{\mathrm{s}}$ & 0.18 & 0.16 \\
\hline $\mathrm{F}_{\mathrm{PS}}$ & 0.195 & 0.18 \\
\hline $\mathrm{S}_{\mathrm{GA}}$ & 0.34 & 0.31 \\
\hline $\mathrm{S}_{G A}+\mathrm{F}_{\mathrm{P}}$ & 0.36 & 0.33 \\
\hline $\mathrm{S}_{\mathrm{GA}}+\mathrm{F}_{\mathrm{S}}$ & 0.35 & 0.305 \\
\hline $\mathrm{S}_{\mathrm{GA}}+\mathrm{F}_{\mathrm{PS}}$ & 0.36 & 0.3 \\
\hline $\mathrm{F}_{\mathrm{GA}}$ & 0.35 & 0.31 \\
\hline $\mathrm{F}_{\mathrm{GAP}}$ & 0.39 & 0.33 \\
\hline $\mathrm{F}_{\mathrm{GAS}}$ & 0.37 & 0.37 \\
\hline $\mathrm{F}_{\text {GAPS }}$ & 0.39 & 0.365 \\
\hline $\mathrm{S}_{\mathrm{GA}}+\mathrm{F}_{\mathrm{GA}}$ & 0.38 & 0.31 \\
\hline $\mathrm{S}_{\mathrm{GA}}+\mathrm{F}_{\mathrm{GAP}}$ & 0.4 & 0.35 \\
\hline $\mathrm{S}_{\mathrm{GA}}+\mathrm{F}_{\mathrm{GAS}}$ & 0.43 & 0.41 \\
\hline $\mathrm{S}_{\mathrm{GA}}+\mathrm{F}_{\mathrm{GAPS}}$ & 0.45 & 0.4 \\
\hline C.D. at $5 \%$ & 0.024 & 0.026 \\
\hline
\end{tabular}

N.B, A uniform basal dose of $40 \mathrm{kgN}+30 \mathrm{~kg}_{2} \mathrm{O}_{5} / \mathrm{ha}$ was given to all pots
The vegetative and reproductive growth of plants depends mainly on their ability to fix $\mathrm{C}$ in organs having chloroplasts followed by the utilization of the photosynthates for sink organs. As the C fixing ability of plants is influenced by mineral elements among other factors, the availability of $\mathrm{P}$ and $\mathrm{S}$ to leguminous plants affects production of dry matter and partitioning of photosynthates. ${ }^{47}$ The enhancing effect of foliar application of $10^{-6} \mathrm{MGA}$ at $60-70 \mathrm{DAS}$ over the water-sprayed control on CA, NR, $P_{\mathrm{N}}, g s$, and Lb (observed at 90 and $100 \mathrm{DAS}$ ) of chickpea cultivars, particularly DCP 92-3 receiving the officially recommended basal dose of $40 \mathrm{kgN}+30 \mathrm{~kg} \mathrm{P}_{2} \mathrm{O}_{5} /$ ha can be traced to its various comparatively more roles in plants. For example, application of GA improves, among other processes, absorption and use efficiency of nutrients, ${ }^{48,49}$ activity of enzymes, ${ }^{50,51}$ cell division and cell enlargement, ${ }^{52,53}$ chlorophyll content, ${ }^{54}$ elongation of internode, membrane permeability, ${ }^{55-57} P_{\mathrm{N}}{ }^{58}$ nucleic acid and protein synthesis, ${ }^{59-61}$ and transport of photosynthates. ${ }^{62}$ The improving effect of the spray of a small quantity of $\mathrm{P}$ and /or $\mathrm{S}$ alone or in combination with the soaking and/or foliar spray treatment of GA over the respective control on the growth parameters (observed at 90and100DAS) of chickpea cultivar DCP 92-3 grown with the recommended basal dose of $\mathrm{N}$ and $\mathrm{P}$ is a noteworthy observation.

The promoting effect of $\mathrm{P}$ and $\mathrm{S}$ on the biochemical parameters can be traced to their previously mentioned various roles in introduction. S also helps in chlorophyll formation ${ }^{63,64}$ and stimulates root growth. ${ }^{65}$ Thus, being important essential nutrients, $\mathrm{P}$ and $\mathrm{S}$ are directly or indirectly involved in growth of chickpea like other crops through the production of metabolic compounds. These metabolites, in turn, encourage the formation and enlargement of new cells in treated plants. It may be added that these results on the improving effect of foliar application of $\mathrm{P}$ and $\mathrm{S}$ broadly corroborate the earlier findings of. ${ }^{66,67}$ The augmenting effect of leaf-applied GA over the water-sprayed control on CA and NR activities of chickpea cultivars particularly DCP 92-3, receiving the recommended basal dose of $40 \mathrm{~kg}$ $\mathrm{N}+30 \mathrm{~kg} \mathrm{P}_{2} \mathrm{O}_{5} /$ ha, studied at 90 and 100 DAS is worth mentioning. The increase in CA and NR activities can be attributes to the hormoneinduced increase in transcription and/or translation of the gene that codes for $\mathrm{CA}^{68,69}$ and $\mathrm{NR}^{70,71}$ to its role in enhancing the permeability of membranes and absorption of nutrients. These results are also in accordance with the data of earlier workers including ${ }^{72,73}$ and $^{14}$ on CA activity; ${ }^{74-76}$ on NR activity; and $\mathrm{d}^{77-80}$ on NPK content.

The enhancing effect of pre-sowing seed treatment for $8 \mathrm{~h}$ and foliar treatment at 60 and $70 \mathrm{DAS}$ with $10^{-6} \mathrm{MGA}$ over their respective water treated control on CA and NR activities of DCP 92-3 cultivar of chickpea grown with the recommended basal dose of $\mathrm{N}$ and $\mathrm{P}$ is a noteworthy observation. This may also be attributed, as for growth characters, to its (GA) roles on one hand and compensation of the 'hidden hunger' for GA by its pre-sowing seed treatment or foliar application on the other. These results also corroborate the findings of $^{81,82}$ on CA activity, of ${ }^{81,82}$ on NR activity and of ${ }^{82}$ for pre-sowing seed treatment and of those mentioned on earlier for these parameters for foliar application of GA. The augmenting effect of foliar spray of $\mathrm{P}$ and /or $\mathrm{S}$ alone or in combination with the soaking and /or foliar spray treatment of GA over the respective control on CA activity, NR activity of chickpea cultivar DCP 92-3 grown with the recommended basal dose of $\mathrm{N}$ and $\mathrm{P}$ is not far to seek. $\mathrm{P}$ and $\mathrm{S}$ being component of the various metabolites involve in the production of organic compounds which in turn encourage the formation and proper supply of proteins to be involved in the formation of enzymes. Hence higher activity of $\mathrm{CA}$ and NR in treated plants. 
Enhanced rate of CA activity of chickpea cultivar DCP-92-3 would have resulted in improving the $P_{\mathrm{N}}$ and $g s$ of treated plants (for $P_{\mathrm{N}}$ and for $\left.g s\right)$. Likewise, increased NR activity might be responsible for increasing biosynthesis of chlorophylls that in turn would have improved $P_{\mathrm{N}}$ of treated plants. Improvement in $\mathrm{N}, \mathrm{P}$ and $\mathrm{K}$ content of cultivar DCP 92-3 (data not published) would also have enhanced content of $\mathrm{Lb}$ content on the other. Higher levels of Lb content would also be responsible for increased content of chlorophylls leading to higher $P_{\mathrm{N}}$. This proposition is further confirmed by correlation studies emphasizing a positive and significant correlation between these pairs of parameters.

\section{Yield attributes and quality parameters}

Treatment $\mathrm{S}_{\mathrm{GA}}+\mathrm{F}_{\mathrm{GAPS}}$ gave the maximum value for pod number per plant. Its effect was, however, equal to that of $\mathrm{S}_{\mathrm{GA}}+\mathrm{F}_{\mathrm{GAS}}$. Treatment $\mathrm{S}_{\mathrm{GA}}+\mathrm{F}_{\mathrm{GAPS}}$ gave $121.72 \%$ higher value than $\mathrm{F}_{\mathrm{W}}$ (Table 7). Treatment $\mathrm{S}_{\mathrm{GA}}+\mathrm{F}_{\mathrm{GAPS}}$ gave the maximum value of seed yield. Its effect was, however, equal to that of $\mathrm{S}_{\mathrm{GA}}+\mathrm{F}_{\mathrm{GAS}}, \mathrm{S}_{\mathrm{GA}}+\mathrm{F}_{\mathrm{GAP}}$ and $\mathrm{S}_{\mathrm{GA}}+\mathrm{F}_{\mathrm{GA}}$. Treatment $\mathrm{S}_{\mathrm{GA}}+\mathrm{F}_{\mathrm{GAPS}}$ gave $86.14 \%$ higher value than $\mathrm{F}_{\mathrm{W}}$ (Figure 1). Treatment $\mathrm{S}_{\mathrm{GA}}+\mathrm{F}_{\mathrm{GAPS}}$ proved best for HI. Its effect was, however, equal to that of $\mathrm{S}_{\mathrm{GA}}+\mathrm{F}_{\mathrm{GAS}}, \mathrm{F}_{\mathrm{GAPS}}, \mathrm{S}_{\mathrm{GA}}+\mathrm{F}_{\mathrm{GAP}}, \mathrm{S}_{\mathrm{GA}}+\mathrm{F}_{\mathrm{PS}}$ and $\mathrm{F}_{\mathrm{GAP}}$. Treatment $\mathrm{S}_{\mathrm{GA}}+\mathrm{F}_{\mathrm{GAPS}}$ gave $91.78 \%$ higher value than $\mathrm{F}_{\mathrm{w}}$ (Table 7). Treatment $\mathrm{S}_{\mathrm{GA}}+\mathrm{F}_{\mathrm{GAPS}}$ gave the maximum value for quality parameters viz., seed protein and carbohydrate content. Its effect was, however, equal to that of $\mathrm{F}_{\mathrm{GAPS}}$, $\mathrm{F}_{\mathrm{GA}}, \mathrm{S}_{\mathrm{GA}}+\mathrm{F}_{\mathrm{GA}}, \mathrm{S}_{\mathrm{GA}}+\mathrm{F}_{\mathrm{GAS}}, \mathrm{F}_{\mathrm{GAS}}, \mathrm{S}_{\mathrm{GA}}+\mathrm{F}_{\mathrm{GAP}}, \mathrm{S}_{\mathrm{GA}}+\mathrm{F}_{\mathrm{S}}, \mathrm{S}_{\mathrm{GA}}+\mathrm{F}_{\mathrm{P}}, \mathrm{F}_{\mathrm{GAP}}, \mathrm{S}_{\mathrm{GA}}$ and $\mathrm{F}_{\mathrm{PS}}$. Treatment $\mathrm{S}_{\mathrm{GA}}+\mathrm{F}_{\mathrm{GAPS}}$ gave $20.59 \%$ and $11 \%$ higher value than $\mathrm{F}_{\mathrm{w}}$ respectively (Figure $2 \&$ Table 8 ). The increase in the number of pods per plant and 100-seed weight resulting from the foliar application of GA in comparison with the water-sprayed control of chickpea cultivar DCP 92-3 receiving the recommended basal dose of $\mathrm{N}$ and $\mathrm{P}$ in is worth mentioning. The increase in the above yield attributes may be traced to its various roles mentioned earlier leading to observed higher values for growth characters and, physiological and biochemical parameters of treated plants.

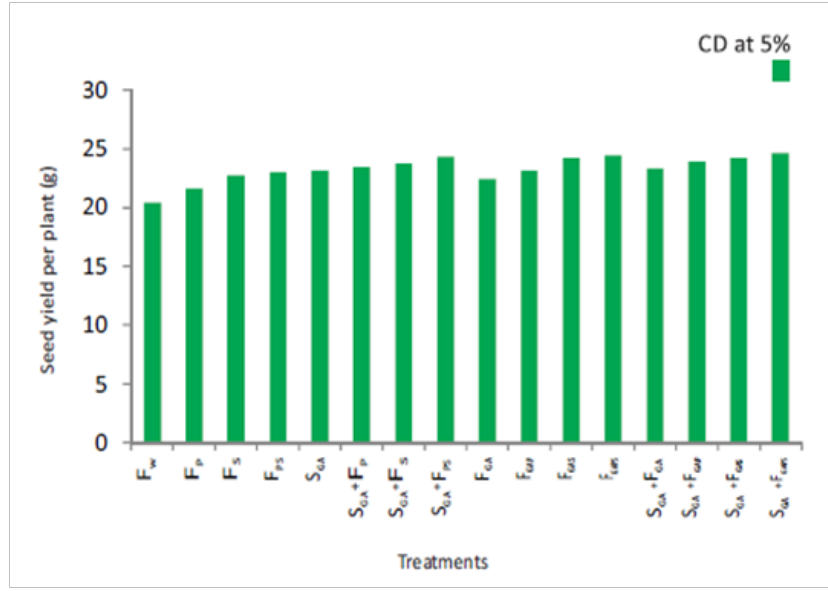

Figure I Effect of spray of $\mathrm{P}$ and / or $\mathrm{S}$ in the presence or absence of soaking and / or spray treatment of GA on seed yield per plant of cultivar DCP 92-3 of chickpea.

Moreover, it mediates differentiation leading to enhanced number of flowers which develop into pods. As mentioned earlier, it plays role in cell division and cell enlargement ${ }^{25-30}$ resulting in proper development of under-developed pods especially at the terminal end of branches; $P_{\mathrm{N}}^{31,32}$ supplying sufficient $\mathrm{C}$ skeleton; and membrane permeability and transport of photosynthates ${ }^{83-85}$ favoring partitioning hence higher values for the yield parameters of treated plants. These results broadly corroborate the findings of ${ }^{86}$ and Shah \& Samiullah. The augmenting effect of pre-sowing seed treatment with $10^{-6} \mathrm{MGA}$ for $8 \mathrm{~h}$ over water-soaking treatment on pods per plant and seeds per pods and of spray treatment at 60 and 70 DAS with the same concentration of GA in comparison with the water-sprayed control on these parameters as also on 100-seed weight in conducted both on chickpea cultivar DCP 92-3 grown with a recommended basal dose of $\mathrm{N}$ and $\mathrm{P}$, is understandable. This may be due to its roles mentioned on earlier for improving these parameters and offset of the 'hidden hunger' for GA by its pre-sowing seed treatment or foliar application. Similar results were also obtained by ${ }^{65-67}$ on pre-sowing seed treatment and by those mentioned on foliar application of GA.

Table 7 Effect of spray of $\mathrm{P}$ and/ or $\mathrm{S}$ in the presence or absence of soaking and / or spray treatment of GA on pod number per plant of chickpea cultivar DCP 92-3 at harvest (mean of four replicates)

\begin{tabular}{ll}
\hline Treatments & Pod number per plant \\
\hline $\mathrm{F}_{\mathrm{W}}$ & 15.2 \\
$\mathrm{~F}_{\mathrm{P}}$ & 17.4 \\
$\mathrm{~F}_{\mathrm{S}}$ & 18.25 \\
$\mathrm{~F}_{\mathrm{PS}}$ & 20.7 \\
$\mathrm{~S}_{\mathrm{GA}}$ & 24.6 \\
$\mathrm{~S}_{\mathrm{GA}}+\mathrm{F}_{\mathrm{P}}$ & 25.1 \\
$\mathrm{~S}_{\mathrm{GA}}+\mathrm{F}_{\mathrm{S}}$ & 28.9 \\
$\mathrm{~S}_{\mathrm{GA}}+\mathrm{F}_{\mathrm{PS}}$ & 27.4 \\
$\mathrm{~F}_{\mathrm{GA}}$ & 27.4 \\
$\mathrm{~F}_{\mathrm{GAP}}$ & 29.5 \\
$\mathrm{~F}_{\mathrm{GAS}}$ & 30.2 \\
$\mathrm{~F}_{\mathrm{GAPS}}$ & 30.7 \\
$\mathrm{~S}_{\mathrm{GA}}+\mathrm{F}_{\mathrm{GA}}$ & 28.9 \\
$\mathrm{~S}_{\mathrm{GA}}+\mathrm{F}_{\mathrm{GAP}}$ & 29.1 \\
$\mathrm{~S}_{\mathrm{GA}}+\mathrm{F}_{\mathrm{GAS}}$ & 33.4 \\
$\mathrm{~S}_{\mathrm{GA}}+\mathrm{F}_{\mathrm{GAPS}}$ & 33.7 \\
$\mathrm{C} . \mathrm{D}$. at $5 \%$ & 1.85 \\
\hline
\end{tabular}

N.B,A uniform basal dose of $40 \mathrm{~kg} \mathrm{~N}+30 \mathrm{~kg} \mathrm{P}_{2} \mathrm{O}_{5} /$ ha was given to all pots

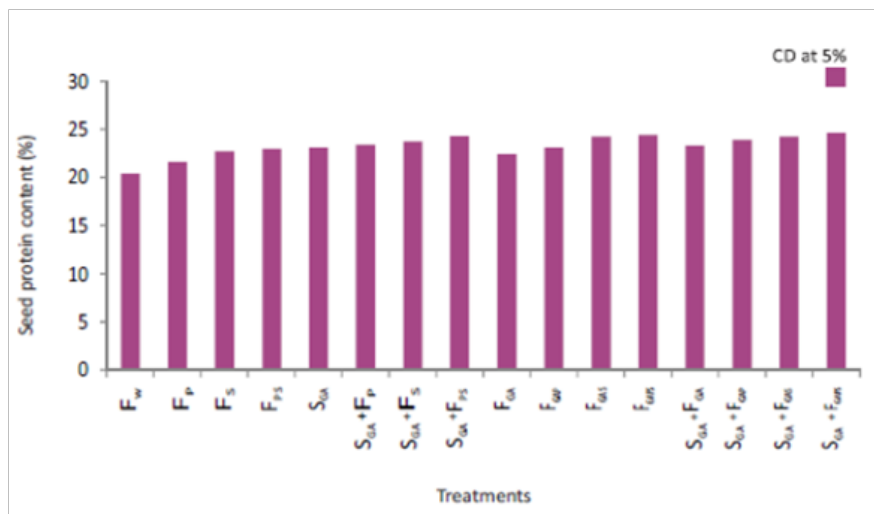

Figure 2 Effect of spray of $\mathrm{P}$ and/or $\mathrm{S}$ in the presence or absence of soaking and / or spray treatment of GA on seed protein content of cultivar DCP 92-3 of chickpea. 
Table 8 Effect of spray of $\mathrm{P}$ and/ or $\mathrm{S}$ in the presence or absence of soakin and / or spray treatment of GA on harvest index of chickpea cultivar DCP 92-3 at harvest (mean of four replicates)

\begin{tabular}{ll}
\hline Treatments & Harvest index (\%) \\
\hline $\mathrm{F}_{\mathrm{W}}$ & 30.4 \\
$\mathrm{~F}_{\mathrm{P}}$ & 41.2 \\
$\mathrm{~F}_{\mathrm{S}}$ & 39.4 \\
$\mathrm{~F}_{\mathrm{PS}}$ & 43.7 \\
$\mathrm{~S}_{\mathrm{GA}}$ & 49.45 \\
$\mathrm{~S}_{\mathrm{GA}}+\mathrm{F}_{\mathrm{P}}$ & 50.2 \\
$\mathrm{~S}_{\mathrm{GA}}+\mathrm{F}_{\mathrm{S}}$ & 53.4 \\
$\mathrm{~S}_{\mathrm{GA}}+\mathrm{F}_{\mathrm{PS}}$ & 55.1 \\
$\mathrm{~F}_{\mathrm{GA}}$ & 52.2 \\
$\mathrm{~F}_{\mathrm{GAP}}$ & 54.75 \\
$\mathrm{~F}_{\mathrm{GAS}}$ & 53.1 \\
$\mathrm{~F}_{\mathrm{GAPS}}$ & 55.9 \\
$\mathrm{~S}_{\mathrm{GA}}+\mathrm{F}_{\mathrm{GA}}$ & 53.8 \\
$\mathrm{~S}_{\mathrm{GA}}+\mathrm{F}_{\mathrm{GAP}}$ & 55.2 \\
$\mathrm{~S}_{\mathrm{GA}}+\mathrm{F}_{\mathrm{GAS}}$ & 57.85 \\
$\mathrm{~S}_{\mathrm{GA}}+\mathrm{F}_{\mathrm{GAPS}}$ & 58.3 \\
$\mathrm{C} . \mathrm{D}$. at $5 \%$ & $\mathrm{NS}$ \\
\hline &
\end{tabular}

N.B,A uniform basal dose of $40 \mathrm{~kg} \mathrm{~N}+30 \mathrm{~kg} \mathrm{P}_{2} \mathrm{O}_{5}$ / ha was given to all pots

Table 9 Effect of spray of $\mathrm{P}$ and/ or $\mathrm{S}$ in the presence or absence of soaking and / or spray treatment of GA on seed carbohydrate content of chickpea cultivar DCP 92-3 at harvest (mean of four replicates)

\begin{tabular}{ll}
\hline Treatments & Seed carbohydrate content (\%) \\
\hline $\mathrm{F}_{\mathrm{W}}$ & 65.2 \\
$\mathrm{~F}_{\mathrm{P}}$ & 66.15 \\
$\mathrm{~F}_{\mathrm{S}}$ & 69.7 \\
$\mathrm{~F}_{\mathrm{PS}}$ & 70 \\
$\mathrm{~S}_{\mathrm{GA}}$ & 70.2 \\
$\mathrm{~S}_{\mathrm{GA}}+\mathrm{F}_{\mathrm{P}}$ & 71 \\
$\mathrm{~S}_{\mathrm{GA}}+\mathrm{F}_{\mathrm{S}}$ & 70.4 \\
$\mathrm{~S}_{\mathrm{GA}}+\mathrm{F}_{\mathrm{PS}}$ & 69.8 \\
$\mathrm{~F}_{\mathrm{GA}}$ & 66.7 \\
$\mathrm{~F}_{\mathrm{GAP}}$ & 67.8 \\
$\mathrm{~F}_{\mathrm{GAS}}$ & 69.1 \\
$\mathrm{~F}_{\mathrm{GAPS}}$ & 70.8 \\
$\mathrm{~S}_{\mathrm{GA}}+\mathrm{F}_{\mathrm{GA}}$ & 68.4 \\
$\mathrm{~S}_{\mathrm{GA}}+\mathrm{F}_{\mathrm{GAP}}$ & 70.9 \\
$\mathrm{~S}_{\mathrm{GA}}+\mathrm{F}_{\mathrm{GAS}}$ & 71.6 \\
$\mathrm{~S}_{\mathrm{GA}}+\mathrm{F}_{\mathrm{GAPS}}$ & 72.4 \\
$\mathrm{C.D}$. at $5 \%$ & 2.04 \\
\hline
\end{tabular}

N.B, A uniform basal dose of $40 \mathrm{~kg} \mathrm{~N}+30 \mathrm{~kg} \mathrm{P}_{2} \mathrm{O}_{5} /$ ha was given to all pots
The improvement in pods per plant, seeds per pod and 100-seed weight of chickpea cultivar DCP 92-3 grown with the recommended basal dose of $\mathrm{N}$ and $\mathrm{P}$, due to foliar application of a small quantity of $\mathrm{P}$ and /or $\mathrm{S}$ alone or in combination with the soaking and /or spray of GA over the respective control is not far to seek. The increase in these parameters due to spray $\mathrm{P}$ and $\mathrm{S}$ can be ascribed to their roles mentioned earlier. Also, $\mathrm{P}$ and $\mathrm{S}$ influence differentiation in plants. ${ }^{86,87}$ The improvement in growth, physiological and biochemical parameters resulted from the spray of these nutrients together with enhancement in differentiation may lead to the improvement in yield parameters, hence higher values for pods per plant, seeds per pod and 100-seed weight. These results are in accordance with the findings of ${ }^{43-86}$ on foliar application of $\mathrm{P}$ and $\mathrm{S}$. The increased yield attributing parameters of treated plants, particularly pods per plant and $^{88,90} 100$-seed weight are likely to have contributed to the improved seed yield. This proposition is confirmed by correlation studies also wherein various yield characters may be noted to the positively and significantly correlated with seed yield. ${ }^{91-95}$ The observed increase in seed protein content due to foliar application and due to pre-sowing seed treatment of GA is not surprising. An improvement in protein synthesis may result from the application of GA and $\mathrm{P}$ and $\mathrm{S}$, hence higher values for seed protein content. ${ }^{96-100}$ These results broadly corroborate with the findings of ${ }^{87}$ on GA application and of on $\mathrm{P}$ and $\mathrm{S}$ although on basal application. It is highly satisfying to note that the results of this pot experiment undertaken above clear show that the author's hypothesis forming the basis of the endeavour under discussion stand confirmed. ${ }^{101-111}$

\section{Conclusion}

In the end, the present author wishes to claim that he has been able to enrich the scientific literature on chickpea by contributing the following new findings: The efficacy of a small quantity of leafapplied $\mathrm{P}$ and $\mathrm{S}$ (each at $2 \mathrm{~kg} / \mathrm{ha})$ along with the best soaking $\left(10^{-6} \mathrm{M}\right.$ GA for $8 \mathrm{~h})$ and spray $\left(10^{-6} \mathrm{MGA}\right.$ at $\left.60 \& 70 \mathrm{DAS}\right)$ treatments was tested and the above combination of nutrients and GA treatments gave the best performance of chickpea cultivar DCP 92-3.

\section{Acknowledgments}

We are grateful to the Dean, R. K. Shukla, Faculty of Applied Sciences and Humanities, Bareilly, for providing research facilities. We are also grateful to Prof D.K. Saxena for his critical comments and valuable suggestions with regard to the preparation of the manuscript.

\section{Conflict of interest}

The author declares that there is no conflict of interest.

\section{References}

1. Raut RS, Sabale RN. Studies on the yield maximization of chickpea cv. Vijay through fertilizer and growth regulator under irrigated condition. $J$ Maharastra agric Univ. 2003;28:311-312.

2. Basir A, Shah Z, Naeem M, et al. Effect of phosphorus and farmyard manure on agronomic traits of chickpea (Cicer arietinum L.). Sarhad J Agric. 2008;24(4):567-572.

3. FAO. Crops statistics-concepts, definitions and classifications. 2012.

4. Iqbal HF, Tahir A, Khalid MN, et al. Response of chickpea (Cicer arietinum L.) growth towards the foliar application of gibberellic acid at different growth stages. Pak J biol Sci. 2001;4(4):433-434.

5. Akter A, Ali E, Islam MMZ, et al. Effect of $\mathrm{GA}_{3}$ on growth and yield of mustard. Int J Sustain Crop Prod. 2007;2(2):16-20. 
6. Rupela O. Nodulation and nitrogen fixation in chickpea. In: The Chickpea, M Saxena et al. editors. CAB International. Wallingford, UK; 1987. p. 191-206.

7. Mazid M, Khan, TA, Mohammad F. Medicinal Plants of rural India: A review of use by Indian folks. Indo Global $J$ Pharmaceu Sci. 2012;2(3):286-304.

8. Mazid M, Zeba HK, Quddusi S, et al. Significance of Sulphur nutrition against metal induced oxidative stress in plants. J Stress Physiol \& Biochem. 2011;7(3):165-184.

9. Ahmad A. Nitrate accumulation and nitrate reductase activity during rooting of pea cuttings treated with auxins. Indian $J$ exp Biol. 1988;26:470-472.

10. Naqvi N, Khan TA, Mazid M, et al. Phytoremediatory potential of Guava and Ashok tree at three different sites of Bareilly district-A case study. ARPN J Agricul Biol sci. 2014;9(3):101-109.

11. Khan F, Mazid M, Khan TA, et al. Plant derived pesticides in control of Lepidopterian insects: Dictum and Directions. Res J Bio. 2014;2(1):1-10.

12. Chaurasia S, Chaurasia AK. Effect of fertility levels and growth regulators on growth and yield of chickpea (Cicer arietinum L.). Crop Res. 2008;36:71-75.

13. Upadhyay RG. Response of growth regulators on flower drop, fruit setting, biochemical constituents and yield of chickpea (Cicer arietinum L.) under mid hill conditions of HP. Leg Res. 2002;25:211-214.

14. Badger MR, Price GD. The role of carbonic anhydrase in photosynthesis. Ann Rev Plant Physiol Plant Mol Biol. 1994;45:369-392.

15. Quddasi S, Khan F, Mazid M, et al. Quality status of nutrients, vitamins and hormones under pathological threats in tomato: Basic scenario. Medi Chemis Anal. 2014;4(1):12-21.

16. Gana AS. The role of synthetic growth hormones in crop multiplication and improvement. African J Biotechnol. 2010;10(51):10330-10334.

17. Naidu CV, Swamy PM. Effect of gibberellic acid on growth biomass production and associated physiological parameters in some selected tree species. Indian J Plant Physiol. 1995;38:15-17.

18. Naidu CV. Improvement of seed germination in red sanders (Pterocarpus santalinus Linn. F) by plant growth regulators. Indian J Plant Physiol. 2001;6(2):205-207.

19. Taiz L, Zeiger E. Plant Physiology. 5th ed. In: Sinauer, Associates, editors. USA: Sunderland; 2010.

20. Mazid M, Khan TA, Mohammad F. Response of crop plants under sulphur stress tolerance: A holistic approach. J Stress Physiol and Biochem. 2011;7(3):23-57.

21. Khan, TA, Mazid M, Mohammad F. Sulphur management: An agronomic and transgenic approach. J Indus Res \& Tech 2011;1(2):147-161.

22. Anonymous. Urea: Foliar Spray on Crops in India. Japan Urea Centre, New Delhi, India; 1971.

23. Gikaara DM, Johnston ME, Edwards DG. Management of phosphorus supply to Australian native plants. Sci Hort. 2004;102: 311-323.

24. Eriksen J, Askegaard M. Sulphate leaching in an organic crop rotation on sandy soil in Denmark. Agric. Ecosyst. Environ. 2000;78(2): 107-114.

25. Marschner H. Mineral Nutrition of Higher Plants. 2nd ed. Academic Press, London, UK; 2002.

26. Matsubayshi Y, Ogawa M, Kihara H, et al. Disruption and overexpression of Arabidopsis phytosulfokine receptor gene affect cellular longevity and potential for growth. Plant Physiol. 2006;142(1):45-53.

27. Hopkins WG. Introduction to Plant Physiology. 2nd ed. Inc: John Wiley \& Sons, New York, USA; 2004.
28. Anonymous. Quarterly Chana Report (August-October). Kotak Commodity Services Ltd, India; 2011. p. 3.

29. Dwivedi RS, Randhawa NS. Evaluation of rapid test for the hidden hunger of zinc in plants. Plant Soil. 1974;40(2):445-451.

30. Jaworski EG. Nitrate reductase assay in intact plant tissues. Biochem. Biophys Res Commun. 1971;43(6):1274-1279.

31. Sadasivan S, Manickam A. Biochemical Methods. 3rd ed. New Age International, New Delhi, India; 2008.

32. Lowry OH, Rosebrough NJ, Farr AL, et al. Protein measurement with the Folin phenol reagent. J Biol Chem. 1951;193(1):265-275.

33. Gomez KA, Gomez AA. Statistical Procedures for Agricultural Research. 2nd ed. New York, USA: J Wiley and Sons;1984.

34. Tripathi DK, Lallu, Bhushan C, et al. Effect of some growth regulators on flower drop and yield of chickpea. J Food Leg. 2007;20:117-118.

35. Zahir ZA, Iqbal M, Arsad M, et al. Effectiveness of IAA, GA, and kinetin blended with recycled organic waste for improving growth and yield of wheat (Triticum aestivum L.). Pak J Bot. 2007;39(3):761-768.

36. Ali S, Bano A. Leaf and nodule senescence in chickpea (Cicer arietinum L.) and the role of plant growth regulators. PakJ Bot. 2008;40:2481-2492.

37. Fatima Z, Bano A, Sial R, et al. Responses of chickpea to plant growth regulators on nitrogen fixation and yield. Pak $J$ Bot. 2008;40(5):2005-2013

38. Mazid M, Khan TA, Mohammad F, et al. Physico-biochemical effects of pre-sowing seed treatment with gibberellic acid on Helianthus annus L. National conference of Plant Physiology" Current Trends in Plant Biology Research". Junagarh, Gujarat, India; 2013. p. 895-896.

39. Bishnoi NR, Krishnamoorthy HN. Effect of water logging and gibberellic acid on leaf gas exchange in peanut (Arachis hypogaea L.). J Plant Physiol. 1992;139(4):503-505.

40. Gupta VN, Datta SK. Influence of gibberellic acid on growth and flowering in chrysanthemum (Chrysanthemum morifolium Rahmat) cv. Jayanti. Indian J Plant Physiol. 2001;6:420-422.

41. Davies PJ. The plant hormones: Their nature, occurrence and functions. In: PJ Davies, editor. Plant Hormones: Biosynthesis, Signal Transduction, Action. $3^{\text {rd }}$ ed. Kluwer Academic Publishers, Dordrecht, The Netherlands; 2004. p. 1-15.

42. Ouzounidou G, Ilias I. Hormone-induced protection of sunflower photosynthetic apparatus against copper toxicity. Biol Plant. 2005;49:223-228.

43. Afridi MMRK, Parvaiz MA, Samiullah. Cumulative role of basal and foliar fertilization in enhancing the yield of Laha-101. J Indian bot Soc. 1983;62:68-72.

44. Tiwari DK, Pandey P, Giri SP, et al. Effect of $\mathrm{GA}_{3}$ and other plant growth regulators on hybrid rice seed production. Asian J Plant Sci. 2011;10(2):133-139.

45. Mazid M, Nazz F. Repercussion of photosynthetic variables and related enzymes under influence of sodium dihydrogen orthophosphate and sodium sulphate with two modes of gibberellic acid application. $\mathrm{Ag} \mathrm{Sci}$ Dig. 2017;37(1):52-56.

46. Mazid M. Seed priming application of gibberellic acid on growth, biochemical, yield and protein status of Chickpea (Cicer arietinum L. cv. DCP 92-3). Inte J Genetic Eng and Biotech. 2014;5(1):17-22.

47. Kharche PV, Kubde KJ, Solunke PS. Effect of phosphorus, sulphur and PSB on quality components and nutrient uptake in chickpea. Ann Plant Physiol. 2006;20:78-81.

48. Singh N, Chen W, Redden R, et al. Chemistry of pulses. In: Chickpea Breeding and Management. In: SS Yadav, Redden, et al. editors. CAB International, Oxfordsire, UK; 2004. p. 110-121. 
49. Mazid M. Some improvement strategies for the sustainable chickpea development: Single or combined application of monosodium phosphate and sodium sulphate with or without gibberellic acid treatment by foliar or seed priming. Leg Res (accepted). India; 2017. p. 660-668.

50. Chanda SV, Sood CR, Reddy VS, et al. Influence of plant growth regulators on some enzymes of nitrogen assimilation in mustard seedling. J Plant Nutr. 1998;21(8):1765-1777.

51. Yuan L, Xu DQ. Stimulation effect of gibberellic acid short-term treatment on leaf photosynthesis related to the increase in rubisco content in broad bean and soybean. Photosynth Res. 2001;68(1):39-47.

52. Arteca RN. Plant Growth Substances: Principles and Applications. Chapman and Hall Inc, New York, USA; 1996.

53. Buchanan BB, Gruissen W, Jones RL. Biochemistry and Molecular Biology of Plants. American Society of Plant physiologists. Rockville, Maryland, USA; 2000

54. Khan MN. Response of Linum usitatissimum L. to the Application of $\mathrm{GA}_{3}, \mathrm{~N}, \mathrm{P}, \mathrm{Ca}$ and $\mathrm{Mg}$. PhD. Thesis, Aligarh Muslim University, Aligarh, India; 2008.

55. Wood A, Paleg LG. Alteration of liposomal membrane fluidity by gibberellic acid. Australian. J Plant Physiol. 1974;1(1):31-40.

56. Crozier A, Turnbull CGN. Gibberellins: Biochemistry and action in extension growth. What's New Plant Physiol. 1984;15:9-12.

57. Bhandal IS, Singh R, Malik CP. Effect of some growth substances and phenolic compounds on membrane permeability in beet root. Phyton. 1985;25:177-184.

58. Afroz S, Mohammad F, Hayat S, et al. Exogenous application of gibberellic acid counteracts the ill effect of sodium chloride in mustard. Turkish J Biol. 2005;29(4):233-236.

59. Pain SK, Dutta JK. Studies on growth and metabolism of Zea mays L.1. The effect of application of gibberellic acid on the growth and metabolism of seedlings. Indian Biol. 1977;9:38-43.

60. Mozer TJ. Control of protein synthesis in barley aleurone layers by the plant hormones gibberellic acid and abscisic acid. Cell. 1980;20(2):479-485.

61. Huttly AK, Phillips AL. Gibberellin-regulated plant genes. Physiol Plant. 1995;95(2):310-317.

62. Estruch JJ, Pereto JG, Vercher Y, et al. Sucrose loading in isolated veins of Pisum sativum: Regulation by abscisic acid, gibberellic acid and cell turgor. Plant Physiol. 1989;91(1):259-265.

63. Prison A. Functional aspects in mineral nutrition of green plants. Ann Rev Plants Physiol. 1955;6:71-114.

64. Nason A, Mc Elroy WD. Modes of action of the essential mineral elements. In: FC Steward, editor. Plant Physiology. A treatise. Vol. III, Inorganic Nutrition of Plants. Academic Press, New York, USA; 1963. p. 451-536.

65. Gilbert FA. The place of sulphur in plant nutrition. Bot Review. 1951;17(9):671-691.

66. Naqvi A, Afridi MMRK, Samiullah. Effect of phosphorus and sulphur on the growth and yield of Laha-101. Geobios. 1977;4:253-254.

67. Khan T. Studies on the Effect of Soil and Foliar Application of Nutrients on the Performance of Mustard. PhD. thesis, Aligarh Muslim University, Aligarh, India; 1993.

68. Okabe K, Yang SY, Tsuzuki M, et al. Carbonic anhydrase: Its content in spinach leaves and its taxonomic diversity studied with anti-spinach leaf carbonic anhydrase antibody. Plant Sci Lett. 1984;33(2):145-153.
69. Sugiharto B, Burnell JN, Sugiyama T. Cytokinin is required to induce the nitrogen dependent accumulation of mRNAs for phosphoenol pyruvate carboxylase and carbonic anhydrase in detached maize leaves. Plant Physiol. 1992;100(1):153-156.

70. Roth Benjerano N, Lips SH. Hormonal regulation of nitrate reductase activity in leaves. New Phytol. 1970;69(1):165-169.

71. Ahmad A. Shoot apex as a source of auxin for nitrate uptake and activity of nitrate reductase in pea cuttings. Indian J exp Biol. 1994;32:65-67.

72. Khan MN, Mohammad F, Siddiqui MH. Pre-sowing seed treatment and foliar application of gibberellic acid improve seed and fibre yield by inducing net photosynthetic rate and carbonic anhydrase activity of linseed genotypes. Int J Plant Develop Biol. 2009;3:34-38.

73. Shah SH, Samiullah. Response of black cumin (Nigella sativa L.) to applied nitrogen with or without gibberellic acid Spray. World J Agric Sci. 2007;3(2):153-158.

74. Sekhon BS, Kumar S, Atwal A, et al. Effect of plant growth hormones and phenolic acids on nitrate reductase activity in moong (Vigna radiata). New Trends Plant Physiol. 1991;4(1):223-226.

75. Khan NA. Effect of gibberellic acid on carbonic anhydrase, photosynthesis, growth and yield of mustard. Boil Plant. 1996;38:145-147.

76. Premabatidevi RK. Effect of IAA, $\mathrm{GA}_{3}$ and kinetin on nitrate reductase and nitrite reductase in the leaves of a tree legume (Perkia javanica Merr). Indian J Plant Physiol. 1998;3(2):97-101.

77. Mukhtar FB. Effect of some plant growth regulators on the growth and nutritional value of Hibiscus sabdariffa L. (red sorrel). Int JP App Scis. 2008;2(3):70-75.

78. Hussein MMM. Effect of gibberellic acid and chemical fertilizers on growth and chemical composition of Cryptostegia grandiflora $\mathrm{R}$. Br. plants. J Hort Sci Orn Plants. 2009;1(2):27-38.

79. Hassan HSA, Sarrwy SMA, Mostafa EAM. Effect of foliar spraying with liquid organic fertilizer, some micro-nutrients, and gibberellins on leaf mineral content, fruit set, yield, and fruit quality of "Hollywood" plum trees. Agric Biol J North Am. 2010;1:638-643.

80. Hassanpouraghdam MB, Hajisamadi AB, Khalighi A. Gibberellic acid foliar application influences growth, volatile oil and some physiological characteristics of lavender (Lavandula officinalis Chaix). Romanian Biotechnol Letters. 2011;16:6322-6327.

81. Shah SH. Photosynthetic and yield responses of Nigella sativa L. to presowing seed treatment with $\mathrm{GA}_{3}$. Turk J Biol. 2007;31:103-107.

82. Jafri N. Study of the Effect of $\mathrm{HA}_{3}$ Application on the Performance of Sunflower. M. Phil. Dissertation, Aligarh Muslim University, Aligarh, India; 2009.

83. Agrawal AK, Badola RC, Kumar R. Impact of foliar spray of growth regulators on nutrient dynamics of Trifolium alexandrium L. Indian bot Soc. 1994;73:550-559.

84. Aloni B, Daie J, Wyse RE. Enhancement of $\left({ }^{14} \mathrm{C}\right)$-sucrose export from source leaves of Vicia faba by gibberellic acid. Plant Physiol. 1986;82:962-966.

85. Daie J, Watts $\mathrm{M}$, Aloni $\mathrm{B}$, et al. In vitro and in vivo modification of sugar transport and translocation in celery by phytohormones. Plant Sci. 1986;46(1):35-41.

86. Mohammad F, Samiullah, Afridi MMRK. Effect of phosphorus spray on mustard yield. Geobios. 1986;13:8-12

87. Khafagy MA. Effects of growth substances, biological boron and their combination on soybean plants under nitrogen levels. J Agric Sci Mansoura Univ. 1995;20:4641-4658. 
88. Jain PC, Kushwaha PS, Dhakad US, et al. Response of chickpea (Cicer arietinum L.) to phosphorus and biofertilizer. Leg Res. 1999;22:241-244.

89. Kumar N, Khangarot SS, Meena RP. Effect of sulphur and plant growthregulators on yield and quality parameters of chickpea (Cicerarietinum L.). Ann Agric Res New Series. 2003;24:434-436.

90. Mansur CP, Palled YB, Halikatti SI, et al. Effect of plant densities and phosphorus levels on seed yield and protein content of Kabuli chickpea genotypes. Karnataka J Agric Sci. 2009;22(2):267-270.

91. Wen G, Chen C, Neill K, et al. Yield response of pea, lentil and chickpea to phosphorus addition in a clay loam soil of central Montana. Arch Agron Soil Sci. 2008;54(1):69-82.

92. Yadav RM, Bharud RW. Response of Kabuli chickpea to the foliar application of growth substances. Mysore J Agri Sci. 2006;40:134-137.

93. Agte VV, Tarwadi KV, Mengale S, et al. Potential of traditionally cooked green leafy vegetables as natural sources for supplementation of eight micronutrients in vegetarian diets. J Food Comp Anal. 2000;13:885-891.

94. Arif N. Effect of soaking and foliar application of gibberellic acid on growth parameters and yield attributing components of moongbean (Vigna radiata L.) Wilczek). Plant Physiol Growth Develop. 2000;13:230-236.

95. Dutta D, Bandyopadhay P. Performance of chickpea (Cicer arietinum L.) to application of phosphorus and bio-fertilizer in laterite soil. Arch Agron Soil Sci. 2009;55(2):147-155.

96. Hasanuzzaman M, Karim MF, Fattah QA, et al. Yield performance of chickpea varieties following application of growth regulator. AmericanEurasian J Scient Res. 2007;2(2):117-120.

97. Karim MF, Fattah QA. Growth analysis of chickpea cv. Bari Chhola-6 as affected by foliar spray of growth regulators. Bangladesh $J$ Bot. 2007;36(2):105-110.

98. Khan TA, Mazid M. Nutritional significance of sulphur in pulse cropping system. Biol and Med. 2011;3(2):114-133.

99. Khan TA, Mazid M, Mohammad F. Status of secondary plant products under abiotic stress: an overview. $J$ of Stress Physiol \& Bioch. 2011;7(2):75-98.

100. Khan NA, Ansari HR, Samiullah. Effect of gibberellic acid spray during ontogeny of mustard on growth, nutrient uptake and yield characteristics. J Agron Crop Sci. 1998;181(1):61-63.
101. Khan NA, Samiullah. Comparative effect of modes of gibberellic acid application on photosynthetic biomass distribution and productivity of rapeseed-mustard. Physiol Mol Biol Plants. 2003;9:141-145.

102. Khan TA, Mazid M, Quddusi S. Role of organic and inorganic chemicals in plant-stress mitigation. Approaches to Plant Stress and their Management. In: PK Gaur, P Sharma, editors. India; 2014. p. 39-52.

103. Mazid M, Khan TA, Mohammad F. Cytokinins, A classical multifaceted hormone in plant system. J Stress Physiol \& Biochem . 2011;7(4):347-368

104. Mobin M, Ansari HR, Khan NA. Timing of GA3 application to Indian mustard (Brassica juncea L.): Dry matter distribution, growth analysis and nutrient uptake. J Agron. 2007;6(1):53-60.

105. Mulligan DR, Patrick JW. Gibberellic-acid-promoted transport of assimilates in stems of Phaseolus vulgaris L: Localised versus remote site (s) of action. Planta. 1979;145(3):233-238.

106. Parvaiz MA, Afridi MMRK, Samiullah. Critical growth stage for optimal response of mustard to foliar application of nitrogen, phosphorus and sulphur. Indian J Plant Nutr. 1982;1:43-48.

107. Samiullah, MohammadF, Afridi MMRK. Onoptimizing mustard yield by spray of nitrogen, phosphorus and sulphar. In: RN Gohil, editor. Recent Trends in Botanical Research. Scientific Publishers, Jodhpur, India; p. 137-143.

108. Sandahya D, Kathuria E, Kakralya BL, et al. Influence of plant growth regulators on photosynthesis in moongbean subjected to water-stress. Indian J Plant Physiol. 2012;17(3 \& 4):241-245.

109. Shah SH. Physiological effects of pre-sowing seed treatment with gibberellic acid on Nigella sativa L. Acta Bot Croat. 2007;66(1):67-73.

110. Shah SH. Effects of nitrogen fertilization on nitrate reductase activity, protein, and oil yields of Nigella sativa L. as affected by foliar GA application. Turk J Bot. 2008;32:165-170.

111. Thakare U, Patil N, Malpathak N. Performance of chickpea under the influence of gibberellic acid and oxygenated peptone during germination. Adv Biosci Biotechnol. 2011;2:40-45. 